\title{
Synthesis, fluxional behavior and structures of diethyldithiophosphate molybdenum complexes: crystal structures of $\left[\mathrm{Et}_{4} \mathrm{~N}\right]\left[\mathrm{Mo}(\mathrm{CO})_{4}\left\{\eta^{2}-\mathrm{S}_{2} \mathrm{P}(\mathrm{OEt})_{2}\right\}\right]$ and $\left[\mathrm{Mo}\left(\mathrm{CH}_{3} \mathrm{CN}\right)\left(\eta^{3}-\mathrm{C}_{3} \mathrm{H}_{5}\right)(\mathrm{CO})_{2}\left\{\eta^{2}-\mathrm{S}_{2} \mathrm{P}(\mathrm{OEt})_{2}\right\}\right]$
}

\author{
Kuang-Hway Yih ${ }^{\mathrm{a}, *}$, Gene-Hsiang Lee ${ }^{\mathrm{b}}$, Yu Wang ${ }^{\mathrm{b}}$ \\ a Department of Applied Cosmetology, Hung Kuang Institute of Technology, Sahlu, Taichung 433, Taiwan \\ ${ }^{\mathrm{b}}$ Department of Chemistry, National Taiwan University, Taipei 106, Taiwan
}

Received 21 April 1999; received in revised form 16 June 1999

\begin{abstract}
The air-sensitive dithiophosphate complexes $\left[\mathrm{Et}_{4} \mathrm{~N}\right]\left[\mathrm{M}(\mathrm{CO})_{4}\left\{\eta^{2}-\mathrm{S}_{2} \mathrm{P}(\mathrm{OEt})_{2}\right\}\right](\mathbf{1}, \mathrm{M}=\mathrm{Mo} ; \mathbf{2}, \mathrm{M}=\mathrm{W})$ are accessible by the reaction of $\mathrm{M}(\mathrm{CO})_{4}(\text { pip })_{2}$ (pip = piperidine) $(\mathrm{M}=\mathrm{Mo}, \mathrm{W})$ with $\mathrm{NH}_{4} \mathrm{~S} \mathrm{P}_{2} \mathrm{P}(\mathrm{OEt})_{2}$ in refluxing acetonitrile in the presence of Et ${ }_{4} \mathrm{NBr}$. Complex 1 reacts with allyl bromide in $\mathrm{CH}_{3} \mathrm{CN}$ to give the complex $\left[\mathrm{Mo}\left(\mathrm{CH}_{3} \mathrm{CN}\right)\left(\eta^{3}-\mathrm{C}_{3} \mathrm{H}_{5}\right)(\mathrm{CO})_{2}\left\{\eta^{2}-\mathrm{S} 2 \mathrm{P}(\mathrm{OEt})_{2}\right\}\right](3)$. The single-crystal structures of complexes $\mathbf{1}$ and $\mathbf{3}$ have been determined by X-ray diffraction analyses. Crystal data for 1: space group, $C 2 / c$ with $a=13.088(7), b=16.271(4), c=11.366(7) \AA, \beta=93.88(5)^{\circ}, V=2414.9(21) \AA^{3}, Z=4$. The structure was refined to $R=0.031$ and $R w=0.031$; Crystal data for 3: space group, Pna $2_{1}$ with $a=15.979(3), b=8.613(2), c=12.720(3) \AA$, $V=1750.6(6)$ $\AA^{3}, Z=4$. The structure was refined to $R=0.026$ and $R w=0.028$. Treatment of 3 with piperidine results in the formation of the complex $\left[\mathrm{Mo}\left(\eta^{3}-\mathrm{C}_{3} \mathrm{H}_{5}\right)(\mathrm{CO})_{2}\left\{\eta^{2}-\mathrm{S}_{2} \mathrm{P}(\mathrm{OEt})_{2}\right\}\left(\mathrm{C}_{5} \mathrm{H}_{10} \mathrm{NH}\right)\right](4)$, in which the labile $\mathrm{CH}_{3} \mathrm{CN}$ ligand was substituted by $\mathrm{C}_{5} \mathrm{H}_{10} \mathrm{NH}$. The rotational behaviors of complex $\mathbf{3}$ and $\mathbf{4}$ in solution state were detected by variable-temperature ${ }^{1} \mathrm{H}-\mathrm{NMR}$ spectroscopy. The mechanism can be described as a trigonal twist, which involves the rotation of the triangular face formed by the nitrogen ligand and the two sulfur atoms relative to the face formed by the allyl and the two carbonyl groups. The 16-electron dithiocarbamate

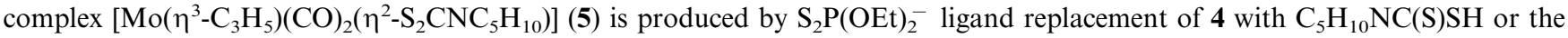
insertion reaction of $\mathrm{CS}_{2}$ into the Mo-N bond of 4 with releasing of the (EtO) ${ }_{2} \mathrm{P}(\mathrm{S}) \mathrm{SH}$ ligand. C) 1999 Elsevier Science S.A. All rights reserved.
\end{abstract}

Keywords: Molybdenum; Diethyldithiophosphato ligand; Trigonal twist; Carbon disulfide; Insertion reaction

\section{Introduction}

The anionic dithiophosphate ligands, $\mathrm{S}_{2} \mathrm{P}(\mathrm{OR})_{2}^{-}$ $(\mathrm{R}=\mathrm{alkyl})$, have proven to be versatile, and can bind as a unidentate [1], chelating [2], or bridging [3] ligand to a wide range of transition metals. These ligands are of interest, in part, due to their use as catalyst additives [4], sequestering agents [5] and isolation of the cubanlike cluster [6]. Although many simple $\mathrm{M}\left\{\mathrm{S}_{2} \mathrm{P}(\mathrm{OEt})_{2}\right\}_{n}$ species have been prepared [7], fewer organometallic dithiophosphate molybdenum complexes except $\mathrm{Cp}$ $\mathrm{Mo}(\mathrm{CO})_{2}\left\{\mathrm{~S}_{2} \mathrm{P}\left(\mathrm{OPr}^{i}\right)_{2}\right\} \quad[8 \mathrm{a}], \quad \mathrm{Mo}(\mathrm{CO})_{2}\left\{\mathrm{~S}_{2} \mathrm{P}(\mathrm{OEt})_{2}\right\}-$

\footnotetext{
* Corresponding author. Fax: + 886-4-6321046.
}

$(\mathrm{NCMe})\left(\mathrm{SnRCl}_{2}\right)[9 \mathrm{a}], \mathrm{Mo}(\mathrm{CO})_{2}\left\{\mathrm{~S}_{2} \mathrm{P}(\mathrm{OEt})_{2}\right\}\left(\mathrm{S}_{2} \mathrm{CPCy}_{3}\right)-$ $\left(\mathrm{SnPhCl}_{2}\right)[9 \mathrm{~b}]$ and $\mathrm{Mo}_{2}\left(\eta^{3}-\mathrm{C}_{3} \mathrm{H}_{5}\right)_{2}(\mathrm{CO})_{4}\left\{\mathrm{~S} 2 \mathrm{P}(\mathrm{OEt})_{2}\right\}_{2}-$ $\left(\mu-\mathrm{NH}_{2} \mathrm{NH}_{2}\right)$ [9c] have been characterized and only rarely subjected to crystallographic study.

Complexes of the type $\left[\mathrm{MoL}\left(\eta^{3}-\mathrm{C}_{3} \mathrm{H}_{5}\right)(\mathrm{CO})_{2} \mathrm{~A}\right](\mathrm{A}$ : pyrazolylborate or $\beta$-diketonate ligand, L: neutral monodentate ligand) have been known for more than 15 years. Notably, the solution rotational behavior [10] and structures [11] of these compounds containing the nitrogen, phosphine, and oxygen bidentate ligands have been studied clearly but no detailed information has been presented on the sulfur-containing bidentate ligand such as $(\mathrm{EtO})_{2} \mathrm{PS}_{2}^{-}$in this rotating system.

In the context of our previous studies on transition metal complexes containing the anionic sulfur ligands, 


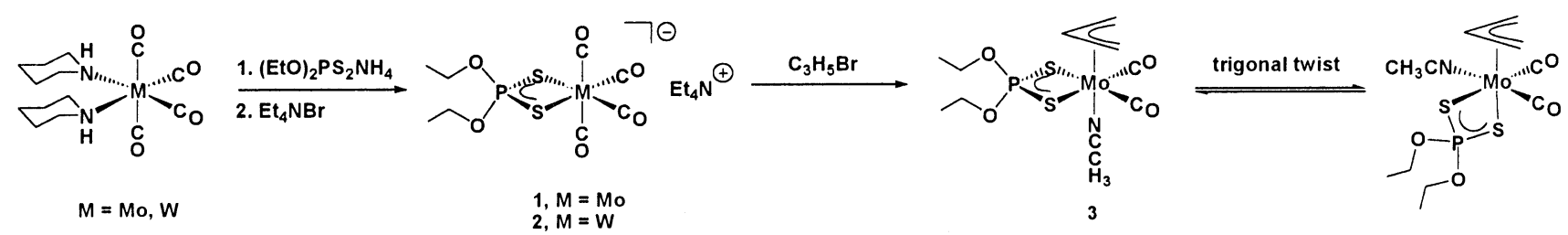

Scheme 1.

$\mathrm{C}_{5} \mathrm{H}_{10} \mathrm{NCS}_{2}^{-}, \mathrm{Ph}_{2} \mathrm{PCS}_{2}^{-}$and $\mathrm{Ph}_{2} \mathrm{PC}(=\mathrm{NPh}) \mathrm{S}^{-}$[12], and in view of above-mentioned interesting results, we extended our investigation to a study of the diethyldithiophosphato, $(\mathrm{EtO})_{2} \mathrm{PS}_{2}^{-}$, ligand. In this paper, we describe the synthesis, structures and the rotational behavior of the $\eta^{3}$-allyl molybdenum complex involving the diethyldithiophosphato, $(\mathrm{EtO})_{2} \mathrm{PS}_{2}^{-}$, ligand.

\section{Results and discussion}

2.1. Synthesis of anionic dithiophosphate complexes

$\left[E t_{4} N\right]\left[M o(C O)_{4}\left\{\eta^{2}-S_{2} P(O E t)_{2}\right\}\right]$ (1) and

$\left[E t_{4} N\right]\left[W(C O)_{4}\left\{\eta^{2}-S_{2} P(O E t)_{2}\right\}\right]$ (2)

The air-sensitive compounds of the type $[\mathrm{Cat}]\left[\mathrm{Mo}(\mathrm{CO})_{4} \mathrm{~L}-\mathrm{L}\right]\left(\mathrm{Cat}=\mathrm{Na}, \mathrm{K}, \mathrm{NH}_{4} ; \mathrm{L}-\mathrm{L}=\right.$ dithiocarbamto, xanthato, dithiophosphato) were prepared by heating $\left(60-65^{\circ} \mathrm{C}\right) \mathrm{Mo}(\mathrm{CO})_{6}[8 \mathrm{~b}]$ or $\mathrm{M}(\mathrm{CO})_{4}(\mathrm{pip})_{2}$ $(\mathrm{M}=\mathrm{Mo}, \mathrm{W})[16]$ with ligand salt in degassed DMSO or $\mathrm{CH}_{3} \mathrm{CN}$, respectively. The $\left[\mathrm{Et}_{4} \mathrm{~N}\right]\left[\mathrm{Mo}(\mathrm{CO})_{4}\left\{\eta^{2}-\right.\right.$ $\left.\left.\mathrm{S}_{2} \mathrm{P}(\mathrm{OEt})_{2}\right\}\right]$ complex has been prepared for use in the ${ }^{95} \mathrm{Mo}-\mathrm{NMR}$ experiment [8a] and these complexes were so unstable that some reports described them as nonisolable [8b]. We used the dithiophosphato ligand $\mathrm{NH}_{4} \mathrm{~S}_{2} \mathrm{P}(\mathrm{OEt})_{2}$ with $\mathrm{M}(\mathrm{CO})_{4}(\text { pip })_{2}(\mathrm{M}=\mathrm{Mo}, \mathrm{W})$ in refluxing $\mathrm{CH}_{3} \mathrm{CN}$ in the presence of $\mathrm{Et}_{4} \mathrm{NBr}$ to lead to the formation of the clean and high-yield dithiophosphate complexes $\left[\mathrm{Et}_{4} \mathrm{~N}\right]\left[\mathrm{M}(\mathrm{CO})_{4}\left\{\eta^{2}-\mathrm{S}_{2} \mathrm{P}(\mathrm{OEt})_{2}\right\}\right] \quad(\mathbf{1}$, $\mathrm{M}=\mathrm{Mo} ; \mathbf{2}, \mathrm{M}=\mathrm{W}$ ) (Scheme 1 ). The two yellow crystalline, very air-sensitive products $\mathbf{1}$ and $\mathbf{2}$ were obtained by recrystallization from $\mathrm{CH}_{2} \mathrm{Cl}_{2}-n$-hexane in 78 and $65 \%$ yield, respectively. Complexes $\mathbf{1}$ and $\mathbf{2}$ are very soluble even in diethyl ether but slightly soluble in $n$-hexane. In the FAB mass spectra, two base peaks with the typical Mo and $\mathrm{W}$ isotope distribution are respectively in agreement with the $\left[\mathrm{M}^{+}+\mathrm{Et}_{4} \mathrm{~N}-\mathrm{CO}\right]$ molecular masses of $\mathbf{1}$ and $\mathbf{2}$. The IR spectra of $\mathbf{1}$ and 2, respectively show two sets of four terminal carbonylstretching bands that reveal a $C_{2 v}\left(2 \mathrm{~A}_{1}+\mathrm{B}_{1}+\mathrm{B}_{2}\right)$ symmetry of carbonyl ligands about the metal center. In the ${ }^{31} \mathrm{P}\left\{{ }^{1} \mathrm{H}\right\}$-NMR spectra of $\mathbf{1}$ and $\mathbf{2}$, two singlets at high field relative to the free $\mathrm{NH}_{4} \mathrm{~S}_{2} \mathrm{P}(\mathrm{OEt})_{2}$ ligand indicate the coordination of the dithiophosphato ligand. The ${ }^{1} \mathrm{H}-\mathrm{NMR}$ spectra comprise the proton resonances of $\mathrm{S}_{2} \mathrm{P}(\mathrm{OEt})_{2}^{-}$and $\mathrm{Et}_{4} \mathrm{~N}^{+}$with the integration ratio 6:4:12:8 of 1 and 2. Two singlets at lowest field in the
${ }^{13} \mathrm{C}\left\{{ }^{1} \mathrm{H}\right\}$-NMR spectra of $\mathbf{1}$ and $\mathbf{2}$ are attributed to the carbon atoms of the two carbonyl groups.

To demonstrate the structure of the first Group $\operatorname{VIB}(0)$ dithiophosphate compound, complex 1 was confirmed by single-crystal X-ray diffraction study. The ORTEP diagram with atom labels is shown in Fig. 1.

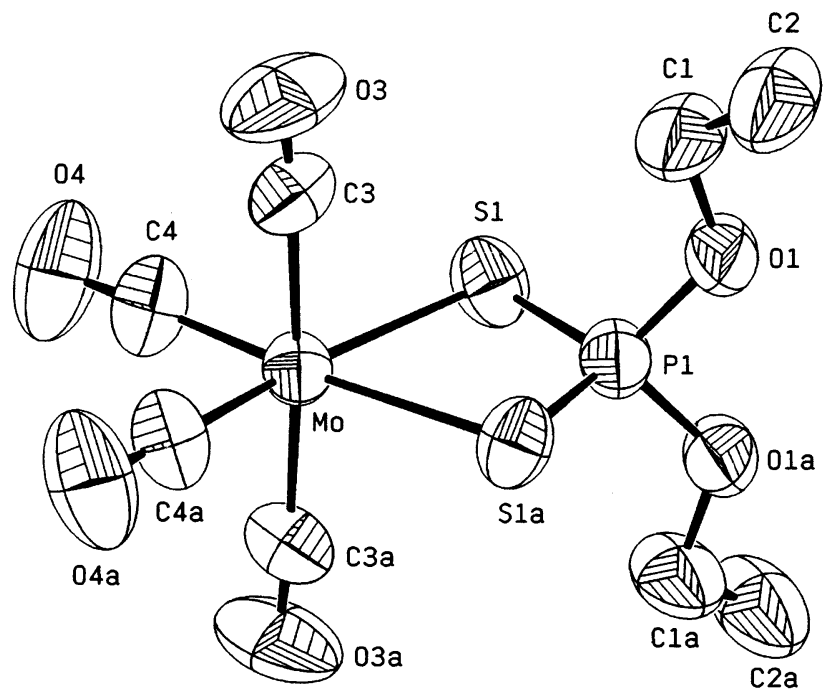

Fig. 1. ORTEP diagram of the anionic complex $\left[\mathrm{Mo}(\mathrm{CO})_{4}\left\{\eta^{2}-\right.\right.$ $\left.\left.\mathrm{S}_{2} \mathrm{P}(\mathrm{OEt})_{2}\right\}\right]^{-}(\mathbf{1})$

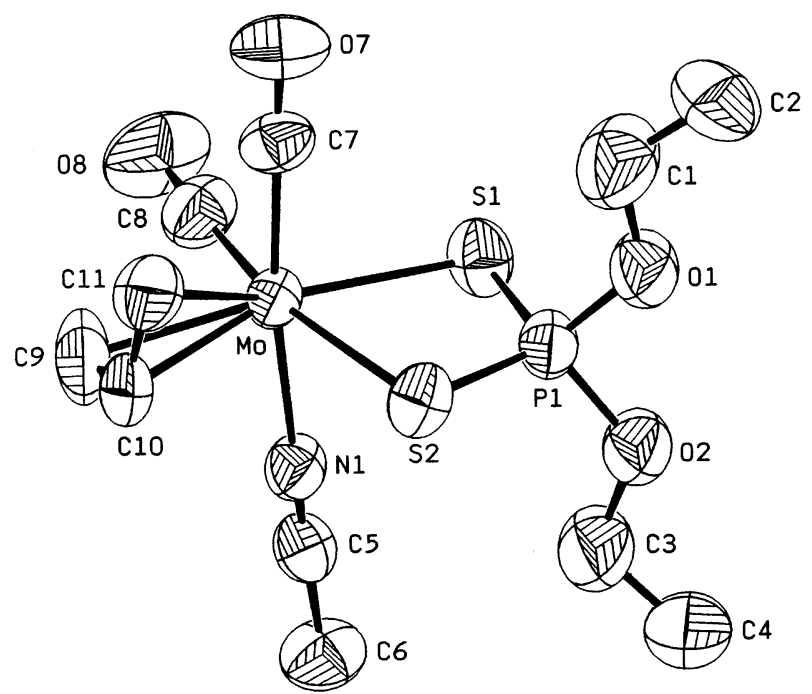

Fig. 2. ORTEP diagram of complex $\left[\mathrm{Mo}\left(\mathrm{CH}_{3} \mathrm{CN}\right)\left(\eta^{3}-\mathrm{C}_{3} \mathrm{H}_{5}\right)(\mathrm{CO})_{2}\left\{\eta^{2}-\right.\right.$ $\left.\left.\mathrm{S}_{2} \mathrm{P}(\mathrm{OEt})_{2}\right\}\right]$ (3). 
Bond distances and bond angles of $\mathbf{1}$ are listed in Table 3. Complex 1 consists of a cation, $\mathrm{Et}_{4} \mathrm{~N}^{+}$, and an anion, $\left[\mathrm{Mo}(\mathrm{CO})_{4}\left\{\eta^{2}-\mathrm{S}_{2} \mathrm{P}(\mathrm{OEt})_{2}\right\}\right]^{-}$. The geometry around the metal atom in the anion is a distorted octahedron with a small $\mathrm{S}(1) \mathrm{MoS}(1 \mathrm{a})$ angle of $75.95(5)^{\circ}$ and a small dihedral angle of $0.38(11)^{\circ}$ between plane $\operatorname{MoS}(1) S(1 a)$ and $\operatorname{MoC}(4) C(4 a)$. The structure of the anion of 1 possesses a $C_{2}$ crystallographic axis through Mo and $\mathrm{P}$ atoms and thus becomes $C_{2 v}$ symmetry. Complex 1 possesses two groups of $\mathrm{Mo}-\mathrm{CO}$ bond distances of 1.924(4) and 2.015(4) $\AA$ due to the trans effect of the carbonyl groups. The Mo-S bond distance of $1(2.622(1) \AA)$ is longer than those of complex $\left[\mathrm{Et}_{4} \mathrm{~N}\right]\left[\mathrm{Mo}(\mathrm{CO})_{4}\left(\eta^{2}-\mathrm{S}_{2} \mathrm{CNEt}_{2}\right)\right]$ [17] (average value of Mo-S bonds, 2.593(1) $\AA$ ) and $\left[\mathrm{Et}_{4} \mathrm{~N}\right]\left[\mathrm{Mo}(\mathrm{CO})_{4}\left(\eta^{2}\right.\right.$ $\left.\mathrm{S}_{2} \mathrm{CNC}_{5} \mathrm{H}_{10}\right)$ ] (2.594(1) $\AA$ ) [12f]. It reflects the $\mathrm{S}_{2} \mathrm{CNEt}_{2}^{-}$ ligand with more $\pi$-acceptor ability than the $\mathrm{S}_{2} \mathrm{P}(\mathrm{OEt})_{2}^{-}$ ligand. In fact, the $\mathrm{S}_{2} \mathrm{P}(\mathrm{OEt})_{2}^{-}$ligand can be replaced by the $\mathrm{S}_{2} \mathrm{CNC}_{5} \mathrm{H}_{10}^{-}$ligand (described below). Compared with the $\mathrm{Mo}(0)-\mathrm{S}_{2} \mathrm{P}(\mathrm{OEt})_{2}$ complex and $\mathrm{Mo}(\mathrm{III}$, $\mathrm{V})-\mathrm{S}_{2} \mathrm{P}(\mathrm{OR})_{2}$ complexes, the Mo-S distance of $\mathbf{1}$ (2.622(1) $\AA$ ) is significantly longer than those observed in the dithiophosphato complexes $\operatorname{Mo}\left\{\mathrm{S}_{2} \mathrm{P}(\mathrm{OMe})_{2}\right\}_{3}$ $(2.501-2.520(2) \AA)$ [7b] and $\left[\left\{\mathrm{MoOS}_{2} \mathrm{P}\left(\mathrm{OPr}^{i}\right)_{2}\right\}_{2} \mathrm{OS}\right]$ $(2.334,2.370(4) \AA)[18]$ in a higher oxidation state. It seems that the higher the Mo oxidation state is, the shorter the Mo-S bond distance becomes.

\subsection{Reaction of complex \\ $\left[E t_{4} N\right]\left[\mathrm{Mo}(\mathrm{CO})_{4}\left\{\eta^{2}-S_{2} P(\mathrm{OEt})_{2}\right\}\right]$ (1) with allyl bromide}

Treatment of $\left[\mathrm{Et}_{4} \mathrm{~N}\right]\left[\mathrm{Mo}(\mathrm{CO})_{4}\left\{\eta^{2}-\mathrm{S}_{2} \mathrm{P}(\mathrm{OEt})_{2}\right\}\right]$ (1) with allyl bromide in $\mathrm{CH}_{3} \mathrm{CN}$ afforded the acetonitrile solvate complex $\left[\mathrm{Mo}\left(\mathrm{CH}_{3} \mathrm{CN}\right)\left(\eta^{3}-\mathrm{C}_{3} \mathrm{H}_{5}\right)(\mathrm{CO})_{2}\left\{\eta^{2}\right.\right.$ $\left.\mathrm{S}_{2} \mathrm{P}(\mathrm{OEt})_{2}\right\}$ ] (3) in $82 \%$ isolate yield. Miguel and coworkers have also described the preparation of complex 3 and several molybdenum-tin, and $\mu-\mathrm{NH}_{2} \mathrm{NH}_{2}$ complexes [9] containing dithiophosphato ligand. All spectroscopic data for $\mathbf{3}$ are consistent with the literature. However, solution IR spectra show the two carbonyls in equal intensity; this observation indicates that the two carbonyls are mutually cis. From an $\mathrm{AM}_{2} \mathrm{X}_{2}$ pattern of the allyl group in the ${ }^{1} \mathrm{H}-\mathrm{NMR}$ spectra and one equivalent resonance of the terminal carbon of the allyl group and one resonance of carbonyl group in the ${ }^{13} \mathrm{C}\left\{{ }^{1} \mathrm{H}\right\}$-NMR spectra, it reveals the bidentate ligand and the two carbonyls lie in a horizontal plane, whereas the allyl group and the $\mathrm{CH}_{3} \mathrm{CN}$ ligand lie in a trans positions above and below the plane, respectively (Scheme 1). Because the mentioned structure is incompatible with the report by Miguel and the corresponding acetonitrile allyl dithiophosphato structure still remains unknown, we have performed an X-ray diffraction study of $\mathbf{3}$ to elucidate the solid-state structure. An ORTEP plot of 3 is shown in Fig. 2. Table 5 shows the
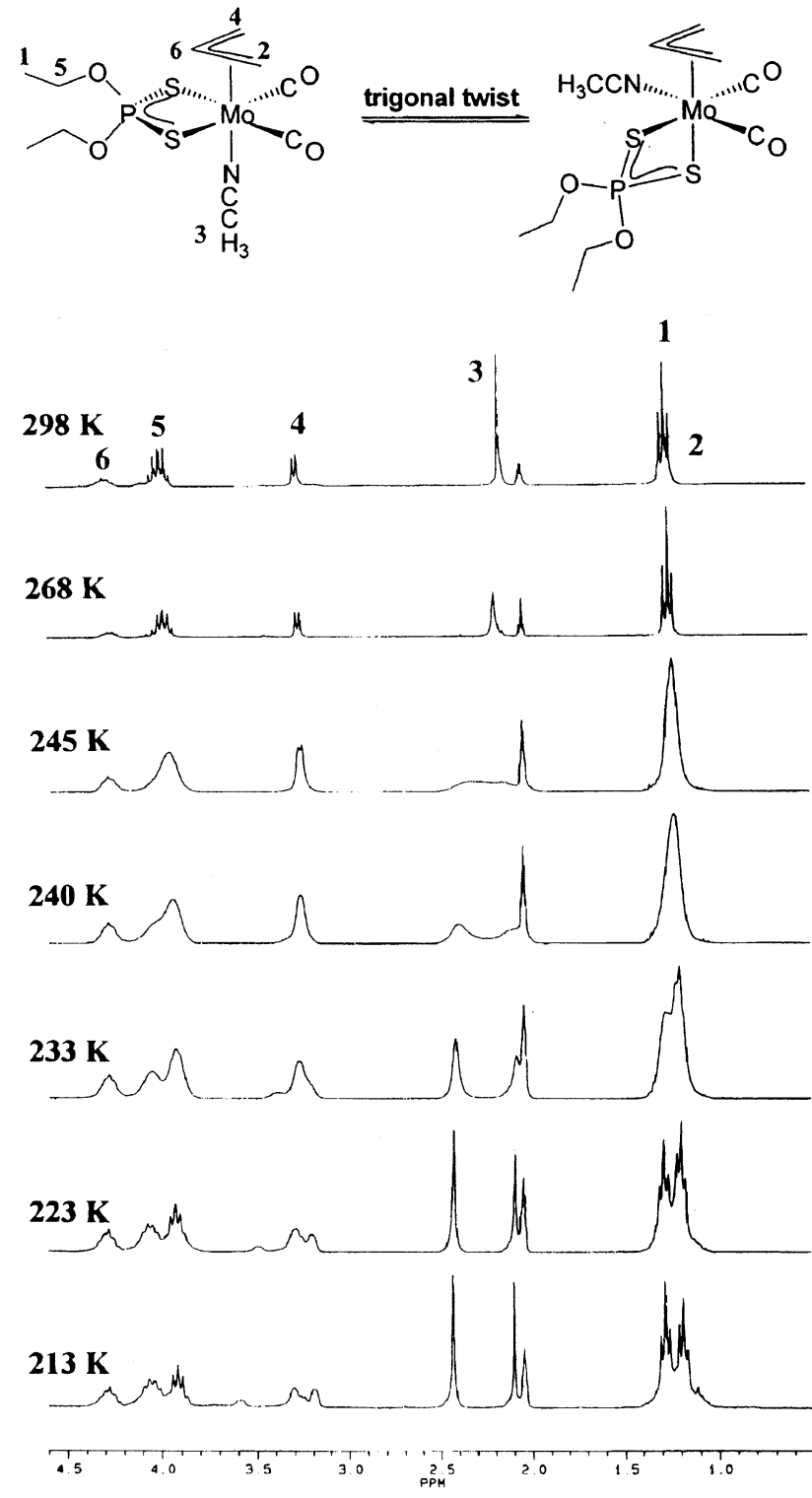

Fig. 3. Variable-temperature ${ }^{1} \mathrm{H}-\mathrm{NMR}$ spectra of 3 in acetone- $d_{6}$.

selected bond distances and bond angles of 3. The coordination geometry around the molybdenum atom is approximately an octahedron with the two dithiophosphato sulfur atoms, acetonitrile, two carbonyls and the allyl group occupying the six coordination sites. The structure confirms an unequivalent allyl group. One of the sulfur atoms of dithiophosphato is trans to the allyl: $\mathrm{S}(1)-\mathrm{Mo}-\mathrm{C}(10), 160.7(2)^{\circ}$, while the other is trans to one carbonyl: $\mathrm{S}(2)-\mathrm{Mo}-\mathrm{C}(8), 167.4(3)^{\circ}$. The remaining carbonyl is trans to the nitrogen atom of the acetonitrile: C(7)-Mo-N, 170.4(2) ${ }^{\circ}$. The S-Mo-S angle of $75.97(7)^{\circ}$ in $\mathbf{3}$ is similar to $75.95(5)^{\circ}$ in $\mathbf{1}$ within experimental errors. The Mo-C(9), C(10) and $\mathrm{C}(11)$ bond distances are 2.297(8), 2.226(7) and 2.339(6) $\AA$, respectively. The Mo-S(1) distance of 2.565(2) $\AA$ (trans 


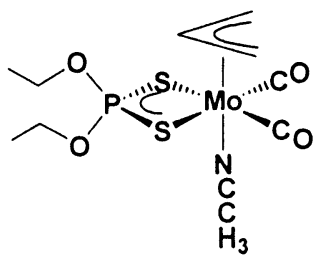

3

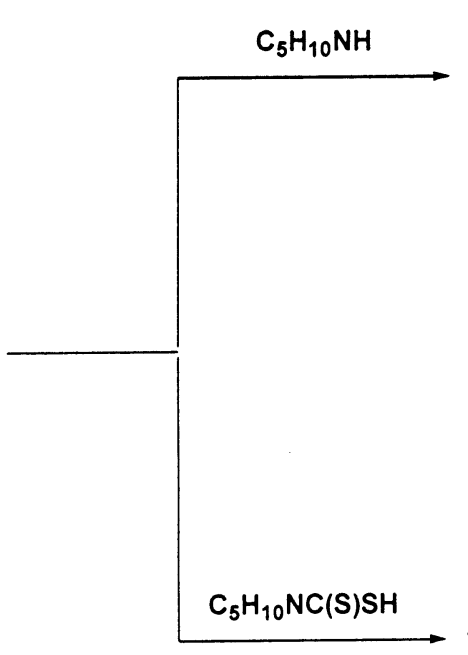

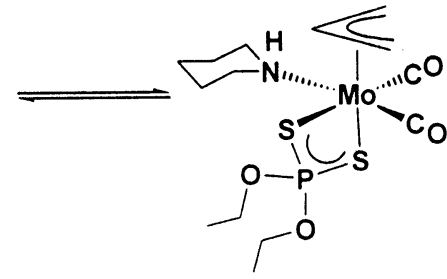

4

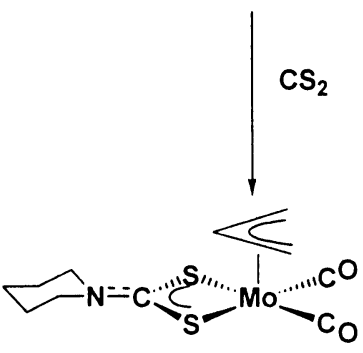

$\mathrm{CS}_{2}$

Scheme 2.

to allyl) is slightly shorter than Mo-S(2) of 2.638(2) $\AA$ (trans to $\mathrm{CO}$ ) because of the greater trans effect induced by the $\mathrm{CO}$ group than the allyl group.

In order to resolve this apparent anomaly between the solution spectroscopy and solid-state structure, the variable-temperature ${ }^{1} \mathrm{H}-\mathrm{NMR}$ experiments were undertaken. By variable-temperature ${ }^{1} \mathrm{H}-\mathrm{NMR}$ spectra, complex $\mathbf{3}$ in solution exhibits fluxional behavior, and the dynamic process has been examined. As depicted in Fig. 3, an $\mathrm{AM}_{2} \mathrm{X}_{2}$ pattern is observed for the allyl protons, and a single resonance for the methyl protons of the acetonitrile group. However, on cooling $\left(\mathrm{CD}_{3}\right)_{2} \mathrm{CO}$ solutions of $\mathbf{3}$, the proton signals initially broaden and below $245 \mathrm{~K}$ the methyl resonance of $\mathrm{CH}_{3} \mathrm{CN}$ and the syn- and anti-proton signals of the allyl moiety each begin to separate into two components. Below $233 \mathrm{~K},{ }^{1} \mathrm{H}-\mathrm{NMR}$ data are in accordance with the two possible structures of $\mathbf{3}$. A ratio of the unsymmetry and symmetry components $(1.2: 1)$ at $213 \mathrm{~K}$ in $\left(\mathrm{CD}_{3}\right)_{2} \mathrm{CO}$ was derived from intensity measurements. The mechanism can be described as a trigonal twist, which involves the rotation of the triangular face formed by the $\mathrm{CH}_{3} \mathrm{CN}$ and the two sulfur atoms relative to the face formed by the allyl and the two carbonyl groups. The rotation mechanism has been previously described for the trigonal twist behavior of $\left[\mathrm{Mo}(\mathrm{pd})\left(\eta^{3}-\mathrm{C}_{3} \mathrm{H}_{5}\right)(\mathrm{CO})_{2}(\mathrm{py})\right]$ [11] and other related complexes [10]. Line-shaped analysis calculated from variable-temperature ${ }^{1} \mathrm{H}-\mathrm{NMR}$ spectra of 3 yields a value of $11.6 \pm 0.2 \mathrm{kcal} \mathrm{mol}^{-1}$ for $\Delta G^{\ddagger}$. Compared with other rearrangement complexes, the activation energy of $\mathbf{3}$ is almost the same as that of complex $\mathrm{Mo}\left(\eta^{3}-\mathrm{C}_{3} \mathrm{H}_{5}\right)(\mathrm{CO})_{2}(\mathrm{dppm}) \mathrm{I}\left(11.2 \mathrm{kcal} \mathrm{mol}^{-1}\right)$ [10d] and is smaller than that of complex
$\left[\mathrm{Mo}(\mathrm{pd})\left(\eta^{3}-\mathrm{C}_{3} \mathrm{H}_{5}\right)(\mathrm{CO})_{2}(\mathrm{py})\right]\left(14.3 \mathrm{kcal} \mathrm{mol}^{-1}\right)[11 \mathrm{~b}]$. Attempts to prepare a similar product from the reaction of $\mathbf{2}$ with allyl bromide were unsuccessful. No reaction occurred under the similar reaction conditions and complex $\mathbf{2}$ decomposed in refluxing conditions.

\subsection{Synthesis of complex $\left[\mathrm{Mo}\left(\eta^{3}-\mathrm{C}_{3} \mathrm{H}_{5}\right)(\mathrm{CO})_{2}\right.$ - $\left.\left\{\eta^{2}-\mathrm{S}_{2} \mathrm{P}(\mathrm{OEt})_{2}\right\}\left(\mathrm{C}_{5} \mathrm{H}_{10} \mathrm{NH}\right)\right]$ (4)}

Complex $\left[\mathrm{Mo}\left(\eta^{3}-\mathrm{C}_{3} \mathrm{H}_{5}\right)(\mathrm{CO})_{2}\left\{\eta^{2}-\mathrm{S}_{2} \mathrm{P}(\mathrm{OEt})_{2}\right\}\left(\mathrm{C}_{5} \mathrm{H}_{10^{-}}\right.\right.$ $\mathrm{NH})$ ] (4) was prepared by the reaction of $\mathbf{3}$ with $\mathrm{C}_{5} \mathrm{H}_{10} \mathrm{NH}$ at ambient temperature (Scheme 2). The yellow compound $\mathbf{4}$ is slightly air-sensitive, soluble in polar solvent, and slightly soluble in $n$-hexane. The FAB mass spectrum of $\mathbf{4}$ shows a parent peak corresponding to the $\left[\mathrm{M}^{+}\right]$molecular mass. Similar spectroscopic phenomena of the carbonyl group and allyl moiety in IR and ${ }^{1} \mathrm{H}-,{ }^{13} \mathrm{C}\left\{{ }^{1} \mathrm{H}\right\}$-NMR spectra led us to believe that complex $\mathbf{4}$ contains the same solution rotational behavior as $\mathbf{3}$. To confirm the result, the variabletemperature ${ }^{1} \mathrm{H}-\mathrm{NMR}$ experiments of $\mathbf{4}$ were carried out. The $\Delta G^{\ddagger}$ value calculated from line-shape analysis of the variable-temperature ${ }^{1} \mathrm{H}-\mathrm{NMR}$ was $12.6 \pm 0.2$ $\mathrm{kcal} \mathrm{mol}^{-1}$ for 4 . The large activation energy of 4 compared with 3 is due to the more steric hindrance of the $\mathrm{C}_{5} \mathrm{H}_{10} \mathrm{NH}$ ligand than $\mathrm{CH}_{3} \mathrm{CN}$. In fact, this value is essentially independent of the nature of the dithiophosphato ligand, increases with increase in the size of the neutral monodentate ligand, and is greater for the substituted allyl than for the allyl complexes. Notably, the dissociation mechanism [11] of the $\mathrm{C}_{5} \mathrm{H}_{10} \mathrm{NH}$ ligand was neglected because when the temperature was increased to $330 \mathrm{~K},{ }^{1} \mathrm{H}-\mathrm{NMR}$ resolved no free $\mathrm{C}_{5} \mathrm{H}_{10} \mathrm{NH}$ signals. 
Table 1

Crystal data and collection parameters for $\mathbf{1}$ and $\mathbf{3}$

\begin{tabular}{|c|c|c|}
\hline & 1 & 3 \\
\hline Formula & $\mathrm{C}_{16} \mathrm{H}_{30} \mathrm{NO}_{6} \mathrm{PS}_{2} \mathrm{Mo}$ & $\mathrm{C}_{11} \mathrm{H}_{18} \mathrm{NO}_{4} \mathrm{PS}_{2} \mathrm{Mo}$ \\
\hline$F_{\mathrm{w}}$ & 523.45 & 419.30 \\
\hline Crystal system & Monoclinic & Orthorhombic \\
\hline Crystal size (mm) & $0.60 \times 0.50 \times 0.50$ & $0.50 \times 0.50 \times 0.40$ \\
\hline Space group & $C 2 / c$ & $P n a 2_{1}$ \\
\hline$a(\AA)$ & $13.008(7)$ & $15.979(3)$ \\
\hline$b(\AA)$ & $16.271(4)$ & $8.613(2)$ \\
\hline$c(\AA)$ & $11.366(7)$ & $12.720(3)$ \\
\hline$\beta\left({ }^{\circ}\right)$ & $93.88(5)$ & \\
\hline$V\left(\AA^{3}\right)$ & $2414.9(21)$ & $1750.6(6)$ \\
\hline$Z$ & 4 & 4 \\
\hline$D_{\text {calc }}\left(\mathrm{g} \mathrm{cm}^{-3}\right)$ & 1.440 & 1.591 \\
\hline$\mu\left(\mathrm{Mo}-\mathrm{K}_{\alpha}\right), \mathrm{mm}^{-1}$ & 1.57 & 1.06 \\
\hline$F(000)$ & 1074 & 842 \\
\hline $2 \theta_{\max }$ & 50.0 & 50.0 \\
\hline Index ranges $(h, k, l)$ & $\begin{array}{l}-15 \rightarrow 15,0 \rightarrow 19 \\
0 \rightarrow 13\end{array}$ & $\begin{array}{l}0 \rightarrow 18,0 \rightarrow 10,0 \rightarrow \\
15\end{array}$ \\
\hline Reflections collected & 2121 & 1618 \\
\hline Observed data $[I>2 \sigma(I)]$ & 1703 & 1364 \\
\hline No. of parameters & 125 & 181 \\
\hline$R^{\mathrm{a}}$ & 0.031 & 0.026 \\
\hline$R w^{\mathrm{b}}$ & 0.031 & 0.028 \\
\hline Max./min. transmission & $0.533,0.565$ & $0.588,0.652$ \\
\hline No. of atoms & 30 & 38 \\
\hline Quality-of-fit ${ }^{c}$ & 1.13 & 1.48 \\
\hline $\begin{array}{l}\Delta(\mathrm{D}-\mathrm{map}) \max . / \mathrm{min} . \\
\quad\left(\mathrm{e} \AA^{-3}\right)\end{array}$ & $-0.340,0.300$ & $-0.320,0.220$ \\
\hline
\end{tabular}

${ }^{\mathrm{a}} R=\Sigma|| F_{\mathrm{o}}|-| F_{\mathrm{c}}|| / \Sigma\left|F_{\mathrm{o}}\right|$.

${ }^{\mathrm{b}} R w=\left[\Sigma \omega\left(\left|F_{\mathrm{o}}\right|-\left|F_{\mathrm{c}}\right|\right)^{2}\right]^{1 / 2}$, where $\omega=1 / \sigma^{2}\left(\left|F_{\mathrm{o}}\right|\right)$.

${ }^{\mathrm{c}}$ Quality-of-fit $=\left[\Sigma \omega\left(\left|F_{\mathrm{o}}\right|-\left|F_{\mathrm{c}}\right|\right)^{2} /\left(N_{\text {reflections }}-N_{\text {parameters }}\right)\right]^{1 / 2}$.

Miguel and co-workers have reported the reactions of 3 with uni- and bidentate nitrogen ligands. Other reactions of 3 with diphos and phenylacetylene will be discussed in a forthcoming paper [19].

\subsection{Preparation of the 16-electron dithiocarbamate complex $\left[\mathrm{Mo}\left(\eta^{3}-\mathrm{C}_{3} \mathrm{H}_{5}\right)(\mathrm{CO})_{2}\left(\eta^{2}-\mathrm{S}_{2} \mathrm{CNC}_{5} \mathrm{H}_{10}\right)\right]$ (5)}

The neutral, 16-electron dithiocarbamate complexes $\left[\mathrm{Mo}\left(\eta^{3}-\mathrm{C}_{3} \mathrm{H}_{5}\right)(\mathrm{CO})_{2}\left(\eta^{2}-\mathrm{S}_{2} \mathrm{CNR}_{2}\right)\right]$ [20] were prepared directly by replacement of $\mathrm{CH}_{3} \mathrm{CN}$ and $\mathrm{Br}$ of complex $\mathrm{Mo}\left(\mathrm{CH}_{3} \mathrm{CN}\right)_{2}\left(\eta^{3}-\mathrm{C}_{3} \mathrm{H}_{5}\right)(\mathrm{CO})_{2} \mathrm{Br}$ by dithiocarbamate ligands. Other methods for synthesis of the dithiocarbamate complexes have been reported by insertion of carbon disulfide into the metal-nitrogen bond [12f,21]. We used complex $\left[\mathrm{Mo}\left(\mathrm{CH}_{3} \mathrm{CN}\right)\left(\eta^{3}-\mathrm{C}_{3} \mathrm{H}_{5}\right)(\mathrm{CO})_{2}\left\{\eta^{2}-\right.\right.$ $\left.\mathrm{S}_{2} \mathrm{P}(\mathrm{OEt})_{2}\right\}$ ] (3) with $\mathrm{C}_{5} \mathrm{H}_{10} \mathrm{NC}(\mathrm{S}) \mathrm{SH}$ in $\mathrm{CH}_{2} \mathrm{Cl}_{2}$ to lead to the formation of the clean and high-yield 16-electron dithiocarbamate complex $\left[\mathrm{Mo}\left(\eta^{3}-\mathrm{C}_{3} \mathrm{H}_{5}\right)(\mathrm{CO})_{2}\left(\eta^{2}\right.\right.$ $\left.\mathrm{S}_{2} \mathrm{CNC}_{5} \mathrm{H}_{10}\right)$ ] (5) with release of $(\mathrm{EtO})_{2} \mathrm{P}(\mathrm{S}) \mathrm{SH}$ ligand (Scheme 2). The yellow-orange crystalline product 5 was slightly air-sensitive, insoluble in $\mathrm{CH}_{2} \mathrm{Cl}_{2}, \mathrm{CH}_{3} \mathrm{CN}$ and only slightly soluble in DMSO. Because of the low solubility, we cannot obtain a good-quality single crys- tal of 5 for X-ray diffraction analysis. In the EI mass spectrum, one parent peak with the typical Mo isotope distribution is in agreement with the $\left[\mathrm{M}^{+}\right]$molecular mass of $\mathbf{5}$. The IR spectrum of $\mathbf{5}$ shows four terminal carbonyl stretching bands and this phenomenon is consistent with other 16-electron complexes $\left[\mathrm{Mo}\left(\eta^{3}\right.\right.$ $\left.\left.\mathrm{C}_{3} \mathrm{H}_{5}\right)(\mathrm{CO})_{2}\left(\eta^{2}-\mathrm{S}_{2} \mathrm{CNR}_{2}\right)\right] \quad$ [20]. The ${ }^{13} \mathrm{C}\left\{{ }^{1} \mathrm{H}\right\}-\mathrm{NMR}$ spectrum of 5 reveals two singlets at lowest field, which are assigned to the carbon atoms of the carbon disulfide and the terminal carbonyl groups, respectively. Complex 5 can also be obtained by the reaction of complex $\left[\mathrm{Mo}\left(\eta^{3}-\mathrm{C}_{3} \mathrm{H}_{5}\right)(\mathrm{CO})_{2}\left\{\eta^{2}-\mathrm{S}_{2} \mathrm{P}(\mathrm{OEt})_{2}\right\}\left(\mathrm{C}_{5} \mathrm{H}_{10} \mathrm{NH}\right)\right]$ (4) with carbon disulfide (Scheme 2). The $\mathrm{CS}_{2}$ insertion reaction into the $\mathrm{M}-\mathrm{N}$ bond $(\mathrm{M}=\mathrm{Cr}, \mathrm{Mo}, \mathrm{W})$ promoted by the abstraction of a proton on the nitrogen atom of the piperidine ligand by ${ }^{n} \mathrm{BuLi}$ to form the $\eta^{2}$-dithiocarbamate ligand has been reported by us [12f]. The reaction of 4 and $\mathrm{CS}_{2}$ is believed to be induced by the stronger $\pi$-acceptor ability of $\mathrm{C}_{5} \mathrm{H}_{10} \mathrm{NCS}_{2}^{-}$ligand, by insertion of $\mathrm{CS}_{2}$ into the Mo-N bond of $\mathbf{4}$ to give dithiocarbamate complex 5 with release of the $(\mathrm{EtO})_{2} \mathrm{P}(\mathrm{S}) \mathrm{SH}$ ligand.

\subsection{Conclusions}

We have investigated the synthesis and structure of the air-sensitive anionic dithiophosphate tetracarbonyl $\mathrm{Mo}(0)$ and $\mathrm{W}(0)$ complexes $\mathbf{1}$ and $\mathbf{2}$, respectively. The variable-temperature ${ }^{1} \mathrm{H}-\mathrm{NMR}$ experiments were used to confirm the trigonal twist behavior of both the stereochemical non-rigidity of $\left[\mathrm{Mo}\left(\mathrm{CH}_{3} \mathrm{CN}\right)\left(\eta^{3}-\right.\right.$ $\left.\left.\mathrm{C}_{3} \mathrm{H}_{5}\right)(\mathrm{CO})_{2}\left\{\eta^{2}-\mathrm{S}_{2} \mathrm{P}(\mathrm{OEt})_{2}\right\}\right]$ (3) and $\left[\mathrm{Mo}\left(\eta^{3}-\right.\right.$ $\left.\left.\mathrm{C}_{3} \mathrm{H}_{5}\right)(\mathrm{CO})_{2}\left\{\eta^{2}-\mathrm{S}_{2} \mathrm{P}(\mathrm{OEt})_{2}\right\}\left(\mathrm{C}_{5} \mathrm{H}_{10} \mathrm{NH}\right)\right]$ (4) at room temperature. The greater $\pi$-acceptor ability of $\mathrm{S}_{2} \mathrm{CNC}_{5} \mathrm{H}_{10}^{-}$than $\mathrm{S}_{2} \mathrm{P}(\mathrm{OEt})_{2}^{-}$induced the insertion reaction of $\mathrm{CS}_{2}$ into the Mo-N bond of 4 to yield the 16-electron complex $\left[\mathrm{Mo}\left(\eta^{3}-\mathrm{C}_{3} \mathrm{H}_{5}\right)(\mathrm{CO})_{2}\left(\eta^{2}-\mathrm{S}_{2} \mathrm{CN}\right.\right.$ $\left.\left.\mathrm{C}_{5} \mathrm{H}_{10}\right)\right](5)$.

\section{Experimental}

\subsection{Materials}

All manipulations were performed under nitrogen using vacuum-line, drybox, and standard Schlenk techniques. NMR spectra were recorded on a Bruker AM200, or on an AM-300 WB FT-NMR spectrometer and are reported in units of $\delta(\mathrm{ppm})$ with residual protons in the solvent as an internal standard $\left(\mathrm{CDCl}_{3}, \delta 7.24\right.$; $\mathrm{CD}_{3} \mathrm{CN}, \delta 1.93 ; \mathrm{C}_{6} \mathrm{D}_{6}, \delta$ 7.15; $\mathrm{C}_{2} \mathrm{D}_{6} \mathrm{CO}, \delta$ 2.04). IR spectra were measured on a Perkin-Elmer 983 instrument and were referenced to a polystyrene standard, using cells equipped with calcium fluoride windows. Mass spectra were recorded on a Jeol SX-102A spectrometer. Solvents were dried and deoxygenated by 
refluxing over the appropriate reagents before use. $n$ Hexane, diethyl ether, THF and benzene were distilled from sodium-benzophenone. Acetonitrile and dichloromethane were distilled from calcium hydride, and methanol from magnesium. All other solvents and reagents were of reagent grade and were used as received. Metal carbonyls, allyl bromide and $\mathrm{NH}_{4} \mathrm{~S}_{2} \mathrm{P}$ $(\mathrm{OEt})_{2}$ were purchased from Strem, Merck and Janssen, respectively. The compounds $\mathrm{M}(\mathrm{CO})_{4}\left(\mathrm{C}_{5} \mathrm{H}_{10} \mathrm{NH}\right)_{2}$ $(\mathrm{M}=\mathrm{Mo}, \mathrm{W})$ [13] were prepared according to the literature methods. Elemental analyses and X-ray diffraction studies were carried out at the Regional Center of Analytical Instrument located at the National Taiwan University.

\section{2. [Tetraethylammonium $]\left[(\right.$ tetracarbonyl $)\left(\eta^{2}-\right.$ diethyldithiophosphato)molybdenum(0)] (1)}

MeCN (40 ml) was added to a flask $(100 \mathrm{ml})$ containing $\mathrm{NH}_{4} \mathrm{~S}_{2} \mathrm{P}(\mathrm{OEt})_{2}(0.406 \mathrm{~g}, 2.0 \mathrm{mmol}), \mathrm{Et}_{4} \mathrm{NBr}(0.535$ $\mathrm{g}, 2.5 \mathrm{mmol})$ and $\mathrm{Mo}(\mathrm{CO})_{4}\left(\mathrm{C}_{5} \mathrm{H}_{10} \mathrm{NH}\right)_{2}(0.756 \mathrm{~g}, 2.0$ $\mathrm{mmol})$. The solution was refluxed for $10 \mathrm{~min}$, and an IR spectrum indicated completion of the reaction. After cooling the solution and removal of the solvent in vacuo, the residue was abstracted with diethyl ether $(3 \times 20 \mathrm{ml})$. Upon cooling below $0^{\circ} \mathrm{C}$, yellow solids of 1 were formed which were isolated by filtration (G4), washed with $n$-hexane $(2 \times 10 \mathrm{ml})$ and subsequently dried under vacuum yielding $0.82 \mathrm{~g}(78 \%)$ of 1 . Further purification was accomplished by recrystallization from 1:10 $\quad \mathrm{CH}_{2} \mathrm{Cl}_{2}-n$-hexane. IR (KBr) $v(\mathrm{CO}) \quad 1999(\mathrm{~m})$, 1861(vs), 1840(vs), 1801(vs) $\mathrm{cm}^{-1} \cdot{ }^{31} \mathrm{P}\left\{{ }^{1} \mathrm{H}\right\}$-NMR (80 $\left.\mathrm{MHz}, \mathrm{C}_{2} \mathrm{D}_{6} \mathrm{CO}, 298 \mathrm{~K}\right): \delta$ 104.6. ${ }^{1} \mathrm{H}-\mathrm{NMR}(200 \mathrm{MHz}$, $\left.\mathrm{C}_{2} \mathrm{D}_{6} \mathrm{CO}, 298 \mathrm{~K}\right): \delta 1.25(\mathrm{t}, J(\mathrm{HH}) 7.4 \mathrm{~Hz}, 6 \mathrm{H}$, $\left.\mathrm{OCH}_{2} \mathrm{CH}_{3}\right), 1.38\left(\mathrm{tt},{ }^{3} J(\mathrm{NH}) 1.9, J(\mathrm{HH}) 7.3 \mathrm{~Hz}, 12 \mathrm{H}\right.$, $\mathrm{NCH}_{2} \mathrm{CH}_{3}$ ), $3.47\left(\mathrm{q}, J(\mathrm{HH}) 7.3 \mathrm{~Hz}, 8 \mathrm{H}, \mathrm{NCH}_{2}\right), 4.03$ (dq, $\left.{ }^{3} J(\mathrm{PH}) 9.5, J(\mathrm{HH}) 7.4 \mathrm{~Hz}, 4 \mathrm{H}, \mathrm{OCH}_{2}\right) .{ }^{13} \mathrm{C}\left\{{ }^{1} \mathrm{H}\right\}-$ NMR (50 MHz, $\left.\mathrm{CDCl}_{3}, 298 \mathrm{~K}\right): \delta 7.5\left(\mathrm{~s}, \mathrm{NCH}_{2} \mathrm{CH}_{3}\right)$, $15.8\left(\mathrm{~s}, \mathrm{OCH}_{2} \mathrm{CH}_{3}\right), 52.6\left(\mathrm{~s}, \mathrm{NCH}_{2}\right), 62.3\left(\mathrm{~s}, \mathrm{OCH}_{2}\right)$, 206.5 (s, cis-CO), 222.1 (s, trans-CO). MS (FAB, NBA) $m / z \quad 627 \quad\left[\mathrm{M}^{+}+\mathrm{Et}_{4} \mathrm{~N}-\mathrm{CO}\right]$. Anal. Calc. for $\mathrm{C}_{16} \mathrm{H}_{30} \mathrm{NO}_{6} \mathrm{PS}_{2} \mathrm{Mo}$ : C, 36.71; H, 5.78; N, 2.68. Found: C, 36.90; H, 5.60; N, 2.50\%.

\section{3. [Tetraethylammonium][(tetracarbonyl) $\left(\eta^{2}\right.$-diethyl- dithiophosphato)tungsten(0)] (2)}

$\mathrm{NH}_{4} \mathrm{~S}_{2} \mathrm{P}(\mathrm{OEt})_{2}(0.406 \mathrm{~g}, 2.0 \mathrm{mmol})$ and $\mathrm{Et}_{4} \mathrm{NBr}$ $(0.535 \mathrm{~g}, 2.5 \mathrm{mmol})$ were dissolved in $\mathrm{MeCN}(20 \mathrm{ml})$ and the solution was added to a solution of $\mathrm{W}(\mathrm{CO})_{4}\left(\mathrm{C}_{5} \mathrm{H}_{10} \mathrm{NH}\right)_{2}(0.932 \mathrm{~g}, 2.0 \mathrm{mmol})$ in $\mathrm{MeCN}$ (40 $\mathrm{ml}$ ). The solution was refluxed for $30 \mathrm{~min}$, and an IR spectrum indicated completion of the reaction. After cooling the solution and removal of the solvent in vacuo, the residue was abstracted with diethyl ether $(3 \times 20 \mathrm{ml})$. Upon cooling below $-18^{\circ} \mathrm{C}$ for 1 day,
Table 2

Atomic parameters $x, y, z$, and $B_{\text {eq }}$ for important atoms of $\mathbf{1}^{\mathrm{a}}$

\begin{tabular}{lllll}
\hline Atom & $x$ & $y$ & $z$ & $B_{\text {eq }}$ \\
\hline Mo & 0 & $0.31337(3)$ & $1 / 4$ & $4.228(19)$ \\
$\mathrm{S}(1)$ & $0.08208(9)$ & $0.18635(7)$ & $0.15031(9)$ & $5.69(5)$ \\
$\mathrm{P}(1)$ & 0 & $0.11565(9)$ & $1 / 4$ & $4.95(7)$ \\
$\mathrm{O}(1)$ & $-0.06698(22)$ & $0.05025(16)$ & $0.1773(3)$ & $6.28(13)$ \\
$\mathrm{C}(1)$ & $-0.1465(4)$ & $0.0764(3)$ & $0.0919(4)$ & $7.7(3)$ \\
$\mathrm{C}(2)$ & $-0.1553(5)$ & $0.0225(3)$ & $-0.0051(5)$ & $9.5(3)$ \\
$\mathrm{C}(3)$ & $-0.1154(3)$ & $0.3177(3)$ & $0.1235(4)$ & $5.91(20)$ \\
$\mathrm{O}(3)$ & $-0.1797(3)$ & $0.3238(3)$ & $0.0522(3)$ & $9.92(21)$ \\
$\mathrm{C}(4)$ & $0.0679(4)$ & $0.3992(3)$ & $0.1687(4)$ & $6.63(24)$ \\
$\mathrm{O}(4)$ & $0.1065(4)$ & $0.45284(22)$ & $0.1221(3)$ & $10.46(24)$ \\
\hline
\end{tabular}

${ }^{a}$ Estimated S.D. values are in parentheses.

Table 3

Selected interatomic distances $(\AA)$ and angles $\left(^{\circ}\right)$ for $\mathbf{1}$

\begin{tabular}{llll}
\hline Mo-S(1) & $2.6219(13)$ & $\mathrm{O}-\mathrm{C}(1)$ & $1.439(5)$ \\
Mo-S(1a) & $2.6219(13)$ & $\mathrm{C}(1)-\mathrm{C}(2)$ & $1.408(7)$ \\
Mo-C(3) & $2.015(4)$ & $\mathrm{C}(3)-\mathrm{O}(3)$ & $1.132(5)$ \\
Mo-C(3a) & $2.015(4)$ & $\mathrm{C}(4)-\mathrm{O}(4)$ & $1.155(5)$ \\
Mo-C(4) & $1.924(4)$ & $\mathrm{Mo}-\mathrm{C}(4 \mathrm{a})$ & $1.924(4)$ \\
$\mathrm{S}(1)-\mathrm{P}(1)$ & $1.9815(16)$ & $\mathrm{P}(1)-\mathrm{S}(1 \mathrm{a})$ & $1.9815(16)$ \\
$\mathrm{P}(1)-\mathrm{O}(1)$ & $1.576(3)$ & $\mathrm{P}(1)-\mathrm{O}(1 \mathrm{a})$ & $1.576(3)$ \\
S(1)-Mo-S(a) & $75.95(5)$ & $\mathrm{S}(1)-\mathrm{P}(1)-\mathrm{O}(1)$ & $113.33(12)$ \\
$\mathrm{S}(1)-\mathrm{Mo}-\mathrm{C}(3)$ & $91.64(12)$ & $\mathrm{S}(1)-\mathrm{P}-\mathrm{O}(1 \mathrm{a})$ & $112.81(12)$ \\
S(1)-Mo-C(3a) & $91.55(14)$ & $\mathrm{Sa}-\mathrm{P}(1)-\mathrm{O}(1)$ & $112.81(12)$ \\
S(1)-Mo-C(4) & $98.55(15)$ & $\mathrm{Sa}-\mathrm{P}(1)-\mathrm{O}(1 \mathrm{a})$ & $113.33(12)$ \\
$\mathrm{S}(1)-\mathrm{Mo}-\mathrm{C}(4 \mathrm{a})$ & $174.50(14)$ & $\mathrm{O}(1)-\mathrm{P}(1)-\mathrm{O}(1 \mathrm{a})$ & $95.08(16)$ \\
S(1a)-Mo-C(3) & $91.55(14)$ & $\mathrm{P}(1)-\mathrm{O}(1)-\mathrm{C}(1)$ & $120.3(3)$ \\
S(1a)-Mo-C(3a) & $91.64(12)$ & $\mathrm{O}(1)-\mathrm{C}(1)-\mathrm{C}(2)$ & $111.2(4)$ \\
S(1a)-Mo-C(4) & $174.50(14)$ & $\mathrm{Mo}-\mathrm{C}(3)-\mathrm{O}(3)$ & $177.0(4)$ \\
S(1a)-Mo-C(4a) & $98.55(15)$ & $\mathrm{Mo}-\mathrm{C}(4)-\mathrm{O}(4)$ & $177.5(4)$ \\
C(3)-Mo-C(3a) & $175.95(18)$ & $\mathrm{C}(3)-\mathrm{Mo}-\mathrm{C}(4)$ & $89.84(20)$ \\
C(3)-Mo-C(4a) & $88.23(19)$ & $\mathrm{C}(3 \mathrm{a})-\mathrm{Mo}-\mathrm{C}(4)$ & $88.23(19)$ \\
C(3a)-Mo-C(4a) & $88.84(20)$ & $\mathrm{C}(4)-\mathrm{Mo}-\mathrm{C}(4 \mathrm{a})$ & $86.94(20)$ \\
Mo-S(1)-P(1) & $87.51(6)$ & $\mathrm{S}(1)-\mathrm{P}(1)-\mathrm{S}(1 \mathrm{a})$ & $109.02(9)$ \\
\hline
\end{tabular}

yellow solids were formed, which were isolated by filtration (G4), washed with cold $\left(0^{\circ} \mathrm{C}\right) n$-hexane $(2 \times$ $10 \mathrm{ml}$ ) and subsequently dried under vacuum to yield $0.79 \mathrm{~g}(65 \%)$ of 2 . Further purification was accomplished by recrystallization from $1: 20 \mathrm{CH}_{2} \mathrm{Cl}_{2}-n$-hexane. IR (KBr) $v(\mathrm{CO})$ 1993(m), 1841(vs), 1833(vs), 1798(vs) $\mathrm{cm}^{-1} \cdot{ }^{31} \mathrm{P}\left\{{ }^{1} \mathrm{H}\right\}$-NMR $\left(80 \mathrm{MHz}, \mathrm{C}_{2} \mathrm{D}_{6} \mathrm{CO}, 298\right.$ $\mathrm{K}): \delta$ 99.0. ${ }^{1} \mathrm{H}-\mathrm{NMR}\left(200 \mathrm{MHz}, \mathrm{CD}_{3} \mathrm{CN}, 298 \mathrm{~K}\right): \delta$ $1.20\left(\mathrm{tt},{ }^{3} J(\mathrm{NH}) 1.9, J(\mathrm{HH}) 7.3 \mathrm{~Hz}, 12 \mathrm{H}, \mathrm{NCH}_{2} \mathrm{CH}_{3}\right)$, $1.28\left(\mathrm{t}, J(\mathrm{HH}) 7.4 \mathrm{~Hz}, 6 \mathrm{H}, \mathrm{OCH}_{2} \mathrm{CH}_{3}\right), 3.16(\mathrm{q}, J(\mathrm{HH})$ $\left.7.3 \mathrm{~Hz}, 8 \mathrm{H}, \mathrm{NCH}_{2}\right), 4.06\left(\mathrm{dq},{ }^{3} J(\mathrm{PH}) 9.5, J(\mathrm{HH}) 7.4\right.$ $\left.\mathrm{Hz}, 4 \mathrm{H}, \mathrm{OCH}_{2}\right) \cdot{ }^{13} \mathrm{C}\left\{{ }^{1} \mathrm{H}\right\}-\mathrm{NMR}\left(50 \mathrm{MHz}, \mathrm{CDCl}_{3}, 298\right.$ $\mathrm{K}): \delta 7.6\left(\mathrm{~s}, \mathrm{NCH}_{2} \mathrm{CH}_{3}\right), 16.2\left(\mathrm{~s}, \mathrm{OCH}_{2} \mathrm{CH}_{3}\right), 52.9(\mathrm{~s}$, $\mathrm{NCH}_{2}$ ), 63.3 (s, $\mathrm{OCH}_{2}$ ), 203.9 (s, cis-CO), 212.0 (s, trans-CO). MS (FAB, NBA) $m / z \quad 713 \quad\left[\mathrm{M}^{+}+\right.$ $\mathrm{Et}_{4} \mathrm{~N}-\mathrm{CO}$. Anal. Calc. for $\mathrm{C}_{16} \mathrm{H}_{30} \mathrm{NO}_{6} \mathrm{PS}_{2} \mathrm{~W}: \mathrm{C}, 31.43$; $\mathrm{H}, 4.95$; N, 2.29. Found: C, 31.65; H, 5.08; N, 2.57\%. 
Table 4

Atomic parameters $x, y, z$, and $B_{\text {eq }}$ for important atoms of $\mathbf{3}^{\text {a }}$

\begin{tabular}{lllll}
\hline Atom & $x$ & $y$ & $z$ & $B_{\text {eq }}$ \\
\hline Mo & $0.59890(3)$ & $0.64115(5)$ & 0.63243 & $3.717(25)$ \\
$\mathrm{S}(1)$ & $0.72332(11)$ & $0.82703(23)$ & $0.65210(17)$ & $5.34(9)$ \\
$\mathrm{S}(2)$ & $0.62411(12)$ & $0.6547(3)$ & $0.83715(16)$ & $4.76(9)$ \\
$\mathrm{P}(1)$ & $0.71659(10)$ & $0.79941(23)$ & $0.80612(18)$ & $4.60(8)$ \\
$\mathrm{O}(1)$ & $0.7102(3)$ & $0.9598(6)$ & $0.8659(4)$ & $6.5(3)$ \\
$\mathrm{C}(1)$ & $0.6437(6)$ & $1.0631(13)$ & $0.8514(9)$ & $9.4(6)$ \\
$\mathrm{C}(2)$ & $0.6505(6)$ & $1.2053(11)$ & $0.9038(9)$ & $8.4(6)$ \\
$\mathrm{O}(2)$ & $0.8021(3)$ & $0.7495(6)$ & $0.8605(4)$ & $6.5(3)$ \\
$\mathrm{C}(3)$ & $0.8384(6)$ & $0.6019(12)$ & $0.8388(10)$ & $8.5(6)$ \\
$\mathrm{C}(4)$ & $0.9113(6)$ & $0.5784(12)$ & $0.8982(11)$ & $10.1(6)$ \\
$\mathrm{N}(1)$ & $0.7014(3)$ & $0.4617(5)$ & $0.6369(6)$ & $4.5(3)$ \\
$\mathrm{C}(5)$ & $0.7539(4)$ & $0.3747(7)$ & $0.6325(8)$ & $4.5(4)$ \\
$\mathrm{C}(6)$ & $0.8233(4)$ & $0.2643(8)$ & $0.6333(9)$ & $6.3(3)$ \\
$\mathrm{C}(7)$ & $0.5258(4)$ & $0.8198(7)$ & $0.6234(7)$ & $5.0(3)$ \\
$\mathrm{O}(7)$ & $0.4835(3)$ & $0.9288(6)$ & $0.6156(5)$ & $7.1(3)$ \\
$\mathrm{C}(8)$ & $0.5997(5)$ & $0.6648(10)$ & $0.4809(7)$ & $5.9(4)$ \\
$\mathrm{O}(8)$ & $0.5987(5)$ & $0.6863(9)$ & $0.3907(5)$ & $9.5(4)$ \\
$\mathrm{C}(9)$ & $0.5343(6)$ & $0.4324(11)$ & $0.5546(9)$ & $7.9(5)$ \\
$\mathrm{C}(10)$ & $0.5129(5)$ & $0.4421(9)$ & $0.6603(7)$ & $5.7(4)$ \\
$\mathrm{C}(11)$ & $0.4634(4)$ & $0.5717(9)$ & $0.6838(6)$ & $6.1(4)$ \\
\hline
\end{tabular}

${ }^{\text {a }}$ Estimated S.D. values are in parentheses.

\section{4. (Acetonitrile) $\left(\eta^{3}\right.$-allyl $)($ dicarbonyl $)\left(\eta^{2}\right.$-diethyl- dithiophosphato)molybdenum(II) (3)}

An aliquot of $\mathrm{C}_{3} \mathrm{H}_{5} \mathrm{Br}(0.1 \mathrm{ml}, 1.2 \mathrm{mmol})$ was added to a flask containing a solution of $1(0.523 \mathrm{~g}, 1.0$ $\mathrm{mmol})$ in $\mathrm{MeCN}(20 \mathrm{ml})$. After stirring for $10 \mathrm{~min}$, the mixture was cooled and the solution was removed in vacuo. The residue was redissolved in $\mathrm{CH}_{2} \mathrm{Cl}_{2}(5 \mathrm{ml})$. $n$-Hexane $(20 \mathrm{ml})$ was added to the solution and a yellow-orange precipitate was formed. The precipitate was collected by filtration (G4) washed with $n$-hexane $(2 \times 10 \mathrm{ml})$ and then dried in vacuo yielding $0.34 \mathrm{~g}$ $(82 \%)$ of 3 . Recrystallization using a mixture of cold 20:1 $\mathrm{MeOH}-\mathrm{CH}_{2} \mathrm{Cl}_{2}$ gave the yellow-orange crystalline product $\left[\mathrm{Mo}-\left(\mathrm{CH}_{3} \mathrm{CN}\right)\left(\eta^{3}-\mathrm{C}_{3} \mathrm{H}_{5}\right)(\mathrm{CO})_{2}\left\{\eta^{2}-\mathrm{S}_{2} \mathrm{P}-\right.\right.$ $\left.\left.(\mathrm{OEt})_{2}\right\}\right]$ (3). IR (KBr) $v(\mathrm{CO}) 1926(\mathrm{vs}), 1841(\mathrm{vs}) \mathrm{cm}^{-1}$. ${ }^{31} \mathrm{P}\left\{{ }^{1} \mathrm{H}\right\}$-NMR $\left(80 \mathrm{MHz}, \mathrm{CD}_{3} \mathrm{CN}, 298 \mathrm{~K}\right): \delta 100.9$. ${ }^{1} \mathrm{H}-\mathrm{NMR}\left(200 \mathrm{MHz}, \mathrm{CD}_{3} \mathrm{CN}, 298 \mathrm{~K}\right): \delta 1.26(\mathrm{t}$, $\left.{ }^{3} J(\mathrm{HH}) 7.4 \mathrm{~Hz}, 6 \mathrm{H}, \mathrm{OCH}_{2} \mathrm{CH}_{3}\right), 1.28(\mathrm{~d}, J(\mathrm{HH}) 10.0$ $\mathrm{Hz}, 2 \mathrm{H}$, Hanti of allyl), 1.95 (s, $\left.3 \mathrm{H}, \mathrm{CH}_{3} \mathrm{CN}\right), 3.29$ (d, $J(\mathrm{HH}) 5.5 \mathrm{~Hz}, 2 \mathrm{H}$, Hsyn of allyl), $4.03\left(\mathrm{dq},{ }^{3} J(\mathrm{PH})\right.$ 9.5, $\left.J(\mathrm{HH}) 7.4 \mathrm{~Hz}, 4 \mathrm{H}, \mathrm{OCH}_{2}\right), 4.29(\mathrm{~m}, 1 \mathrm{H}, \mathrm{CH}$ of allyl). ${ }^{13} \mathrm{C}\left\{{ }^{1} \mathrm{H}\right\}$-NMR $\left(50 \mathrm{MHz}, \mathrm{CD}_{3} \mathrm{CN}, 298 \mathrm{~K}\right): \delta 3.3$ (s, $\left.\mathrm{CH}_{3} \mathrm{CN}\right), 15.8\left(\mathrm{~s}, \mathrm{OCH}_{2} \mathrm{CH}_{3}\right), 55.7\left(\mathrm{~s}, \mathrm{CH}=\mathrm{CH}_{2}\right)$, $62.9\left(\mathrm{~s}, \mathrm{OCH}_{2}\right), 71.5\left(\mathrm{~s}, \mathrm{CH}_{2}=\mathrm{CH}\right), 119.5\left(\mathrm{~s}, \mathrm{CH}_{3} \mathrm{CN}\right)$, 225.0 (s, CO). MS (FAB, NBA): $m / z 421\left[\mathrm{M}^{+}\right], 380$ $\left[\mathrm{M}^{+}-\mathrm{CH}_{3} \mathrm{CN}\right], \quad 339 \quad\left[\mathrm{M}^{+}-\mathrm{CH}_{3} \mathrm{CN}-\mathrm{C}_{3} \mathrm{H}_{5}\right], \quad 311$ $\left[\mathrm{M}^{+}-\mathrm{CH}_{3} \mathrm{CN}-\mathrm{C}_{3} \mathrm{H}_{5}-\mathrm{CO}\right], \quad 283 \quad\left[\mathrm{M}^{+}-\mathrm{CH}_{3} \mathrm{CN}-\right.$ $\mathrm{C}_{3} \mathrm{H}_{5}-2 \mathrm{CO}$. Anal. Calc. for $\mathrm{C}_{11} \mathrm{H}_{18} \mathrm{NO}_{4} \mathrm{PS}_{2} \mathrm{Mo}$ : C, 31.51; H, 4.33; N, 3.34. Found: C, 31.70; H, 4.21; N, $3.25 \%$.
Table 5

Selected interatomic distances $(\AA)$ and angles $\left(^{\circ}\right)$ for $\mathbf{3}$

\begin{tabular}{|c|c|c|c|}
\hline Mo-S(1) & $2.5648(18)$ & $\mathrm{P}(1)-\mathrm{O}(2)$ & $1.590(5)$ \\
\hline Mo-S(2) & $2.6377(21)$ & $\mathrm{O}(1)-\mathrm{C}(1)$ & $1.399(11)$ \\
\hline Mo-N(1) & $2.253(5)$ & $\mathrm{C}(1)-\mathrm{C}(2)$ & $1.398(15)$ \\
\hline $\mathrm{Mo}-\mathrm{C}(7)$ & $1.936(6)$ & $\mathrm{O}(2)-\mathrm{C}(3)$ & $1.425(11)$ \\
\hline Mo-C(8) & $1.939(9)$ & $C(3)-C(4)$ & $1.403(13)$ \\
\hline Mo-C(9) & $2.297(8)$ & $\mathrm{N}(1)-\mathrm{C}(5)$ & $1.126(7)$ \\
\hline Mo-C(10) & $2.226(7)$ & $C(5)-C(6)$ & $1.461(8)$ \\
\hline Mo-C(11) & $2.339(6)$ & $\mathrm{C}(7)-\mathrm{O}(7)$ & $1.160(8)$ \\
\hline $\mathrm{S}(1)-\mathrm{P}(1)$ & $1.976(3)$ & $\mathrm{C}(8)-\mathrm{O}(8)$ & $1.162(11)$ \\
\hline $\mathrm{S}(2)-\mathrm{P}(1)$ & $1.973(3)$ & $C(9)-C(10)$ & $1.390(15)$ \\
\hline $\mathrm{P}(1)-\mathrm{O}(1)$ & $1.581(5)$ & $\mathrm{C}(10)-\mathrm{C}(11)$ & $1.400(12)$ \\
\hline $\mathrm{S}(1)-\mathrm{Mo}-\mathrm{S}(2)$ & $75.97(7)$ & $\mathrm{C}(9)-\mathrm{Mo}-\mathrm{C}(10)$ & $35.7(4)$ \\
\hline $\mathrm{S}(1)-\mathrm{Mo}-\mathrm{N}(1)$ & $82.09(12)$ & $\mathrm{C}(9)-\mathrm{Mo}-\mathrm{C}(11)$ & $60.3(3)$ \\
\hline $\mathrm{S}(1)-\mathrm{Mo}-\mathrm{C}(7)$ & $88.70(18)$ & $\mathrm{C}(10)-\mathrm{Mo}-\mathrm{C}(11)$ & $35.6(3)$ \\
\hline $\mathrm{S}(1)-\mathrm{Mo}-\mathrm{C}(8)$ & $91.5(3)$ & Mo-S(1)-P(1) & $88.82(8)$ \\
\hline $\mathrm{S}(1)-\mathrm{Mo}-\mathrm{C}(9)$ & $151.5(3)$ & Mo-S(2)-P(1) & $86.84(10)$ \\
\hline $\mathrm{S}(1)-\mathrm{Mo}-\mathrm{C}(10)$ & $160.73(20)$ & $\mathrm{S}(1)-\mathrm{P}(1)-\mathrm{S}(2)$ & $108.36(12)$ \\
\hline $\mathrm{S}(1)-\mathrm{Mo}-\mathrm{C}(11)$ & $148.19(20)$ & $\mathrm{S}(1)-\mathrm{P}(1)-\mathrm{O}(1)$ & $112.05(24)$ \\
\hline $\mathrm{S}(2)-\mathrm{Mo}-\mathrm{N}(1)$ & $83.94(20)$ & $\mathrm{S}(1)-\mathrm{P}(1)-\mathrm{O}(2)$ & $114.64(24)$ \\
\hline $\mathrm{S}(2)-\mathrm{Mo}-\mathrm{C}(7)$ & $96.6(3)$ & $\mathrm{S}(2)-\mathrm{P}(1)-\mathrm{O}(1)$ & $114.05(22)$ \\
\hline $\mathrm{S}(2)-\mathrm{Mo}-\mathrm{C}(8)$ & $167.4(3)$ & $\mathrm{S}(2)-\mathrm{P}(1)-\mathrm{O}(2)$ & $112.68(24)$ \\
\hline $\mathrm{S}(2)-\mathrm{Mo}-\mathrm{C}(9)$ & $121.9(3)$ & $\mathrm{O}(1)-\mathrm{P}(1)-\mathrm{O}(2)$ & $94.7(3)$ \\
\hline $\mathrm{S}(2)-\mathrm{Mo}-\mathrm{C}(10)$ & $88.37(23)$ & $\mathrm{P}(1)-\mathrm{O}(1)-\mathrm{C}(1)$ & $122.8(5)$ \\
\hline $\mathrm{S}(2)-\mathrm{Mo}-\mathrm{C}(11)$ & $82.94(19)$ & $\mathrm{O}(1)-\mathrm{C}(1)-\mathrm{C}(2)$ & $115.7(8)$ \\
\hline $\mathrm{N}(1)-\mathrm{Mo}-\mathrm{C}(7)$ & $170.36(21)$ & $\mathrm{P}(1)-\mathrm{O}(2)-\mathrm{C}(3)$ & $120.5(5)$ \\
\hline $\mathrm{N}(1)-\mathrm{Mo}-\mathrm{C}(8)$ & $95.3(3)$ & $\mathrm{O}(2)-\mathrm{C}(3)-\mathrm{C}(4)$ & $111.3(8)$ \\
\hline $\mathrm{N}(1)-\mathrm{Mo}-\mathrm{C}(9)$ & $78.5(3)$ & $\mathrm{Mo}-\mathrm{N}(1)-\mathrm{C}(5)$ & $175.4(7)$ \\
\hline $\mathrm{N}(1)-\mathrm{Mo}-\mathrm{C}(10)$ & $85.20(24)$ & $\mathrm{N}(1)-\mathrm{C}(5)-\mathrm{C}(6)$ & $176.5(10)$ \\
\hline $\mathrm{N}(1)-\mathrm{Mo}-\mathrm{C}(11)$ & $119.36(23)$ & $\mathrm{Mo}-\mathrm{C}(7)-\mathrm{O}(7)$ & $177.9(6)$ \\
\hline $\mathrm{C}(7)-\mathrm{Mo}-\mathrm{C}(8)$ & $82.0(3)$ & $\mathrm{Mo}-\mathrm{C}(8)-\mathrm{O}(8)$ & $176.7(7)$ \\
\hline $\mathrm{C}(7)-\mathrm{Mo}-\mathrm{C}(9)$ & $109.0(3)$ & Mo-C(9)-C(10) & $69.3(4)$ \\
\hline $\mathrm{C}(7)-\mathrm{Mo}-\mathrm{C}(10)$ & $104.4(3)$ & Mo-C(10)-C(9) & $74.9(5)$ \\
\hline $\mathrm{C}(7)-\mathrm{Mo}-\mathrm{C}(11)$ & $70.2(3)$ & $\mathrm{Mo}-\mathrm{C}(10)-\mathrm{C}(11)$ & $76.6(4)$ \\
\hline $\mathrm{C}(8)-\mathrm{Mo}-\mathrm{C}(9)$ & $69.9(4)$ & $\mathrm{C}(9)-\mathrm{C}(10)-\mathrm{C}(11)$ & $113.2(8)$ \\
\hline $\mathrm{C}(8)-\mathrm{Mo}-\mathrm{C}(10)$ & $104.1(3)$ & Mo-C(11)-C(10) & $67.8(4)$ \\
\hline $\mathrm{C}(8)-\mathrm{Mo}-\mathrm{C}(11)$ & $108.1(3)$ & & \\
\hline
\end{tabular}

\section{5. $\left(\eta^{3}\right.$-Allyl)(dicarbonyl) $\left(\eta^{2}\right.$-diethyldithiophosphato)-} (piperidine)molybdenum(II) (4)

A solution of $\left[\mathrm{Mo}\left(\mathrm{CH}_{3} \mathrm{CN}\right)\left(\eta^{3}-\mathrm{C}_{3} \mathrm{H}_{5}\right)(\mathrm{CO})_{2}\left\{\eta^{2}-\right.\right.$ $\left.\left.\mathrm{S}_{2} \mathrm{P}(\mathrm{OEt})_{2}\right\}\right]$ (3) $(0.419 \mathrm{~g}, 1.0 \mathrm{mmol})$ in $\mathrm{CH}_{2} \mathrm{Cl}_{2}(20 \mathrm{ml})$ was treated with $\mathrm{C}_{5} \mathrm{H}_{10} \mathrm{NH}(0.1 \mathrm{ml}, 1.2 \mathrm{mmol})$ at ambient temperature. Instantly, the reaction mixture turned yellow. After $10 \mathrm{~min}$ of stirring, the solution was dried in vacuo. Subsequently, $n$-hexane $(40 \mathrm{ml})$ was added to the solution and a yellow precipitate was formed. The precipitate was collected by filtration (G4) and dried in vacuo to yield $0.35 \mathrm{~g}(76 \%)$ of 4 . IR $(\mathrm{KBr}) v(\mathrm{CO})$ 1929(vs), 1833(vs) $\mathrm{cm}^{-1}$. ${ }^{31} \mathrm{P}\left\{{ }^{1} \mathrm{H}\right\}-\mathrm{NMR}(80 \mathrm{MHz}$, $\left.\mathrm{CDCl}_{3}, 298 \mathrm{~K}\right): \delta 110.4 .{ }^{1} \mathrm{H}-\mathrm{NMR}\left(200 \mathrm{MHz}, \mathrm{CDCl}_{3}\right.$, $298 \mathrm{~K}): \delta 1.12(\mathrm{~d}, J(\mathrm{HH}) 9.4 \mathrm{~Hz}, 2 \mathrm{H}$, Hanti of allyl), $1.33\left(\mathrm{t},{ }^{3} \mathrm{~J}(\mathrm{HH}) 7.4 \mathrm{~Hz}, 6 \mathrm{H}, \mathrm{OCH}_{2} \mathrm{CH}_{3}\right), 1.77(\mathrm{~m}, 6 \mathrm{H}$, $\left.\mathrm{NCH}_{2} \mathrm{CH}_{2} \mathrm{CH}_{2}\right) 3.25(\mathrm{~d}, J(\mathrm{HH}) 6.6 \mathrm{~Hz}, 2 \mathrm{H}$, Hsyn of allyl), $3.53\left(\mathrm{~m}, 4 \mathrm{H}, \mathrm{NCH}_{2}\right), 3.90(\mathrm{~m}, 1 \mathrm{H}, \mathrm{CH}$ of allyl), $4.08\left(\mathrm{dq},{ }^{3} J(\mathrm{PH})\right.$ 9.5, $\left.J(\mathrm{HH}) 7.4 \mathrm{~Hz}, 4 \mathrm{H}, \mathrm{OCH}_{2}\right)$. ${ }^{13} \mathrm{C}\left\{{ }^{1} \mathrm{H}\right\}$-NMR $\left(50 \mathrm{MHz}, \mathrm{CDCl}_{3}, 298 \mathrm{~K}\right): \delta 16.0(\mathrm{~s}$, 
$\left.\mathrm{OCH}_{2} \mathrm{CH}_{3}\right), 23.8 \quad\left(\mathrm{~s}, \quad \mathrm{NCH}_{2} \mathrm{CH}_{2} \mathrm{CH}_{2}\right), 28.9$ (s, $\left.\mathrm{NCH}_{2} \mathrm{CH}_{2}\right), 53.0\left(\mathrm{~s}, \mathrm{NCH}_{2}\right), 57.0\left(\mathrm{~s}, \mathrm{CH}=\mathrm{CH}_{2}\right), 63.0$ (s, $\mathrm{OCH}_{2}$ ), $71.4\left(\mathrm{~s}, \mathrm{CH}_{2}=C \mathrm{H}\right), 227.0$ (s, CO). MS (FAB, NBA): $m / z 464\left[\mathrm{M}^{+}\right], 436\left[\mathrm{M}^{+}-\mathrm{CO}\right], 408\left[\mathrm{M}^{+}-\right.$ 2CO]. Anal. Calc. for $\mathrm{C}_{14} \mathrm{H}_{26} \mathrm{NO}_{4} \mathrm{PS}_{2} \mathrm{Mo}: \mathrm{C}, 36.28 ; \mathrm{H}$, 5.66; N, 3.02. Found: C, 36.25; H, 5.61; N, 3.12\%.

\section{6. $\left(\eta^{3}-\right.$ Allyl $)($ dicarbonyl $)\left(\eta^{2}\right.$-piperidine $-N-$ dithiocarbamato)molybdenum(II) (5)}

\subsubsection{Method A}

A solution of $\mathrm{C}_{5} \mathrm{H}_{10} \mathrm{NC}(\mathrm{S}) \mathrm{SH}(0.161 \mathrm{~g}, 1.0 \mathrm{mmol})$ in $\mathrm{MeOH}(5 \mathrm{ml})$ was added to a flask containing 3 (0.419 $\mathrm{g}, 1.0 \mathrm{mmol})$ in $\mathrm{CH}_{2} \mathrm{Cl}_{2}(20 \mathrm{ml})$. The solution was stirred for $1 \mathrm{~min}$ and a yellow-orange precipitate formed. The precipitate was collected by filtration (G4), washed with $n$-hexane $(2 \times 10 \mathrm{ml})$ and then dried in vacuo to yield $0.35 \mathrm{~g}(99 \%)$ of $\mathbf{5}$. IR ( $\mathrm{KBr}) v(\mathrm{CO})$ 1945(vs), 1917(vs), 1865(vs), 1847(vs) $\mathrm{cm}^{-1} \cdot{ }^{1} \mathrm{H}-\mathrm{NMR}$ $\left(200 \mathrm{MHz}, \mathrm{DMSO}-d_{6}, 298 \mathrm{~K}\right): \delta 1.17(\mathrm{~d}, J(\mathrm{HH}) 9.8 \mathrm{~Hz}$, $2 \mathrm{H}$, Hanti of allyl), $1.50\left(\mathrm{~m}, 6 \mathrm{H}, \mathrm{NCH}_{2} \mathrm{CH}_{2} \mathrm{CH}_{2}\right), 3.13$ (d, $J(\mathrm{HH}) 6.4 \mathrm{~Hz}, 2 \mathrm{H}$, Hsyn of allyl), $3.83(\mathrm{~m}, 4 \mathrm{H}$, $\left.\mathrm{NCH}_{2}\right), 4.00\left(\mathrm{~m}, 1 \mathrm{H}, \mathrm{CH}\right.$ of allyl). ${ }^{13} \mathrm{C}\left\{{ }^{1} \mathrm{H}\right\}-\mathrm{NMR}(50$ $\left.\mathrm{MHz}, \mathrm{DMSO}-d_{6}, 298 \mathrm{~K}\right): \delta 23.7\left(\mathrm{~s}, \mathrm{NCH}_{2} \mathrm{CH}_{2} \mathrm{CH}_{2}\right.$ ), $25.7\left(\mathrm{~s}, \mathrm{NCH}_{2} \mathrm{CH}_{2}\right), 48.0\left(\mathrm{~s}, \mathrm{NCH}_{2}\right), 58.1\left(\mathrm{~s}, \mathrm{CH}=\mathrm{CH}_{2}\right)$, $74.7\left(\mathrm{~s}, \mathrm{CH}_{2}=\mathrm{CH}\right), 204.2$ (s, $\left.\mathrm{CS}_{2}\right), 230.1$ (s, CO). MS (EI, $20 \mathrm{eV}): m / z \quad 355\left[\mathrm{M}^{+}\right], 327\left[\mathrm{M}^{+}-\mathrm{CO}\right], 299$ $\left[\mathrm{M}^{+}-2 \mathrm{CO}\right]$. Anal. Calc. for $\mathrm{C}_{11} \mathrm{H}_{15} \mathrm{NO}_{2} \mathrm{~S}_{2} \mathrm{Mo}$ : C, 37.39; H, 4.28; N, 3.97. Found: C, 37.52; H, 4.42; N, $3.75 \%$.

\subsubsection{Method B}

An aliquot of $\mathrm{CS}_{2}(0.1 \mathrm{ml}, 1.6 \mathrm{mmol})$ was added to a solution of $4(0.463 \mathrm{~g}, 1.0 \mathrm{mmol})$ in $\mathrm{CH}_{2} \mathrm{Cl}_{2}(20 \mathrm{ml})$. Instantly, the reaction was completed. A yellow-orange precipitate was formed which was isolated by filtration (G4), and was washed with $n$-hexane $(2 \times 10 \mathrm{ml})$ and subsequently dried under vacuum to yield $0.33 \mathrm{~g}(94 \%)$ of 5 .

\subsection{X-ray crystallography}

A single crystal of $\mathbf{1}$ suitable for X-ray diffraction analysis was grown by recrystallization from 20:1 $n$ hexane- $\mathrm{CH}_{2} \mathrm{Cl}_{2}$. The diffraction data were collected at room temperature on an Enraf-Nonius CAD4 diffractometer equipped with graphite-monochromated $\mathrm{Mo}-$ $\mathrm{K}_{\alpha}(\lambda=0.71073 \AA)$ radiation. The raw intensity data were converted to structure factor amplitudes and their estimated S.D. values, after corrections for scan speed, background, Lorentz, and polarization effects. An empirical absorption correction, based on the azimuthal scan data, was applied to the data. Crystallographic computations were carried out on a Microvax III computer using the NRCC-SDP-VAX structure determination package [14].
A suitable single crystal of $\mathbf{1}$ was mounted on the top of a glass fiber with glue. Initial lattice parameters were determined from 24 accurately centered reflections with $2 \theta$ values in the range from 19.42 to $24.34^{\circ}$. Cell constants and other pertinent data were collected and are recorded in Table 1. Reflection data were collected using the $\theta / 2 \theta$ scan method. The final scan speed for each reflection was determined from the net intensity gathered during an initial prescan and ranged from 2.06 to $8.24^{\circ} \mathrm{min}^{-1}$. The $\theta$ scan angle was determined for each reflection according to the equation, $0.70 \pm 0.35$ $\tan \theta$. Three check reflections were measured every 30 min throughout the data collection and showed no apparent decay. The merging of equivalent and duplicate reflections gave a total of 2121 unique measured data in which 1703 reflections with $I>2 \sigma(I)$ were considered observed. The structure was first solved by using the heavy-atom method (Patterson synthesis), which revealed the positions of metal atoms. The remaining atoms were found in a series of alternating difference Fourier maps and least-squares refinements. The quantity minimized by the least-squares program was $\omega\left(\left|F_{\mathrm{o}}\right|-\left|F_{\mathrm{c}}\right|\right)^{2}$, where $\omega$ is the weight of a given operation. The analytical forms of the scattering factor tables for the neutral atoms were used [15]. The non-hydrogen atoms were refined anisotropically. Hydrogen atoms were included in the structure factor calculations in their expected positions on the basis of idealized bonding geometry but were not refined in least-squares. The final residuals of this refinement were $R=0.031$ and $R w=0.031$. Final values of all refined atomic positional parameters and selected bond distances and angles are listed in Tables 2 and 3, respectively.

The procedures for $\mathbf{3}$ were similar to those for $\mathbf{1}$. The unit cell constants were also determined from 24 accurately centered reflections. Cell constants and other pertinent data were collected in Table 1. The final residuals of this refinement were $R=0.026$ and $R w=$ 0.028 for 3 . Final values of all refined atomic positional parameters and selected bond distances and angles are listed in Tables 4 and 5, respectively. Tables of thermal parameters are given in the supplementary material.

\section{Supplementary material}

Complete tables of anisotropic thermal parameters, bond distances and bond angles (six pages); listings of observed and calculated structure factors (14 pages) are available from the authors.

\section{Acknowledgements}

We thank the National Science Council of Taiwan, Republic of China for support. 


\section{References}

[1] (a) E. Lindner, H. Berke, J. Organomet. Chem. 39 (1972) 145. (b) D.J. Cole-Hamilton, T.A. Stephenson, J. Chem. Soc. Dalton Trans. (1974) 739.

[2] (a) D.J. Cole-Hamilton, T.A. Stephenson, J. Chem. Soc. Dalton Trans. (1975) 754. (b) D.J. Cole-Hamilton, T.A. Stephenson, J. Chem. Soc. Dalton Trans. (1978) 486. (c) M.E. Nobel, J.C. Huffman, R.A.D. Wentworth, Inorg. Chem. 23 (1984) 631.

[3] (a) J.H. Burk, G.E. Whitwell II, J.T. Lemley, J.M. Burlitch, Inorg. Chem. 22 (1983) 1306. (b) M.H. Chisholm, D.M. Ho, J.C. Huffman, W.G. Van Der Sluys, Polyhedron 6 (1987) 1115. (c) R.W. Hilts, M. Cowie, Inorg. Chem. 29 (1990) 3349.

[4] (a) M. Iglesias, C. Del Pino, S. Martnez-Carrera, Polyhedron 8 (1989) 484. (b) S.G. Kukes, R.J. Hogan, D.M. Coombs, T. Davis, H.F. Efner, Eur. Pat. Appl. EP 160839, 1984; Chem. Abstr. 104 (1986) 53448z. (c) L.J. Velenyi, C. Paparizos, S.R. Dolhyj, US Patent 4262153, 1987; Chem. Abstr. 95 (1981) $80475 \mathrm{~h}$.

[5] (a) W. Bechmann, E. Uhlemann, M.Z. Raab, Anorg. Allg. Chem. 530 (1985) 213. (b) T.A. Udalova, Y.M. Uhlemann, Russ. J. Inorg. Chem. (Engl. Transl.) 28 (1983) 396.

[6] (a) A.W. Edelbult, K. Folting, J.C. Huffman, R.A.D. Wentworth, J. Am. Chem. Soc. 103 (1981) 1927. (b) M.E. Noble, K. Folting, J.C. Huffman, R.A.D. Wentworth, Inorg. Chem. 23 (1984) 631. (c) J.E. Pelati, J.C. Huffman, R.A.D. Wentworth, Inorg. Chem. 27 (1988) 2194.

[7] (a) I. Haiduc, Rev. Inorg. Chem. 3 (1981) 353. (b) J.R. Dilworth, J. Chem. Soc. Dalton Trans. (1983) 397.

[8] (a) S. Woodward, U. Riaz, M.D. Curtis, Organometallics 9 (1990) 2703. (b) M.R. Houchin, K. Mitsios, Inorg. Chim. Acta 65 (1982) L147.

[9] (a) G. Barrado, D. Miguel, J.A. Perez-Martinez, V. Riera, S. Garcia-Granda, J. Organomet. Chem. 463 (1993) 127. (b) G. Barrado, D. Miguel, J.A. Perez-Martinez, V. Riera, J. Organomet. Chem. 466 (1994) 147. (c) G. Barrado, D. Miguel, V. Riera, S. Garcia-Granda, J. Organomet. Chem. 489 (1995) 129.

[10] (a) S. Trofimenko, Acc. Chem. Res. 4 (1971) 17. (b) F.A.
Cotton, A.G. Stanislowski, J. Am. Chem. Soc. 96 (1974) 5074. (c) D.J. Bevan, R.J. Mawby, J. Chem. Soc. Dalton Trans. (1980) 1904. (d) J.W. Faller, D.A. Haitko, R.D. Adams, D.F. Chodosh, J. Am. Chem. Soc. 101 (1979) 865.

[11] (a) B.J. Brisdon, G.F. Griffin, J. Chem. Soc. Dalton Trans. (1975) 1999. (b) B.J. Brisdon, A.A. Woolf, J. Chem. Soc. Dalton Trans. (1978) 291.

[12] (a) K.H. Yih, Y.C. Lin, M.C. Cheng, Y. Wang, J. Chem. Soc. Chem. Commun. (1993) 1380. (b) K.H. Yih, Y.C. Lin, M.C. Cheng, Y. Wang, Organometallics 13 (1994) 1561. (c) K.H. Yih, Y.C. Lin, M.C. Cheng, Y. Wang, J. Organomet. Chem. 474 (1994) C34. (d) K.H. Yih, Y.C. Lin, G.H. Lee, Y. Wang, J. Chem. Soc. Chem. Commun. (1995) 223. (e) K.H. Yih, Y.C. Lin, M.C. Cheng, Y. Wang, J. Chem. Soc. Dalton Trans. (1995) 1305. (f) K.H. Yih, S.C. Chen, Y.C. Lin, M.C. Cheng, Y. Wang, J. Organomet. Chem. 494 (1995) 149. (g) K.H. Yih, S.C. Yeh, Y.C. Lin, G.H. Lee, Y. Wang, Organometallics 17 (1998) 513.

[13] D.J. Darensbourg, R.L. Kump, Inorg. Chem. 17 (1978) 2680.

[14] E.J. Gabe, F.L. Lee, Y. Lepage, in: G.M. Sheldrick, C. Kruger, R. Goddard (Eds.), Crystallographic Computing 3, Clarendon Press, Oxford, 1985, p. 167.

[15] (a) International Tables for X-ray Crystallography, vol. IV, Reidel, Dordrecht, 1974. (b) Y. LePage, E. Gabe, J. Appl. Crystallogr. 23 (1990) 406.

[16] K.B. Shiu, S.M. Peng, M.C. Cheng, S.L. Wang, F.L. Liao, J. Organomet. Chem. 461 (1993) 111.

[17] B. Zhuang, L. Huang, L. He, Y. Yang, J. Lu, Inorg. Chim. Acta 145 (1988) 225.

[18] M.G.B. Drew, P.C.H. Mitchell, A.R. Read, J. Chem. Soc. Chem. Commun. (1982) 238.

[19] K.H. Yih, Y.C. Lin, G.H. Lee, Y. Wang, Chem. Commun. (Cambridge), submitted for publication.

[20] K.B. Shiu, K.H. Yih, S.L. Wang, F.L. Liao, J. Organomet. Chem. 420 (1991) 359.

[21] (a) D.C. Bradley, M.H. Gitlitz, J. Chem. Soc. A (1969) 1152. (b) B.J. McCormick, R.I. Kaplan, Can. J. Chem. 48 (1970) 1876. (c) E. Roman, D. Catheline, D. Astruc, J. Organomet. Chem. 236 (1982) 229. (d) R. Rossi, A. Marchi, A. Duatti, L. Magon, J. Chem. Soc. Dalton Trans. (1988) 899. 